Kristin Veel, lektor, Institut for Kunst- og Kulturvidenskab, Københavns Universitet,

\title{
Fortællingens dynamiske arkiv Fortælleformer og narrativt begær i SKAM
}

\begin{abstract}
With a starting point in the success that the netdrama series SKAM has had in engaging its audience in an almost addictive relation, this article examines how the series makes use of formal techniques such as repetition, intermissions and a minute-by-minute temporality to generate what may be considered a "narrative desire", with a classic term borrowed from literary scholar Peter Brooks. I here argue that the mode of narration that arises from the amorphous, transmedial and fan-engaging universe that is SKAM, resonates with the characteristics of the dynamic, digital archive and the particular spatial and temporal configuration, which the possibilities of digital technology create for production, storage, distribution and consumption of text, sound and images.
\end{abstract}

Keywords: fortælleformer, big data, SKAM, narrativt begær, gentagelse, mellemrum, temporalitet

Fortællingens dynamiske arkiv: Fortælleformer og narrativt begær i SKAM

\begin{abstract}
Hver og en er en viktig del av det store kaoset. Og det du gjør i dag, har en effekt i morgen. Det kan være vanskelig å si hvilken effekt. Og man klarer som regel ikke å se hvordan det hele henger sammen. Men effekten av handlingene dine er der alltid. Et sted $\mathrm{i}$ kaoset. Om hundre år har vi kanskje maskiner som kan regne ut effekten av hver eneste handling. Men inntil da kan vi stole på dette: Frykt sprer seg. Men: Det gjør heldigvis kjærlighet òg.
\end{abstract}

Med disse ord i voice-over afsluttes fjerde og sidste sæson af netdramaserien og succesfænomenet SKAM, som netop kredser om fællesskabet som konstituerende. Det er det, der bærer vores hårdtprøvede og skamfyldte teenagere igennem livets kvaler i både stor og lille skala. Brugen af kaosteoriens sommerfugleeffekt, som bærende metafor i den afsluttende scene, tydeligg ør, hvordan forholdet mellem årsag og virkning og muligheden for at forudsige effekten af vores handlinger har været et centralt tema $\mathrm{i}$ den afsluttende sæson. I billedsekvensen, som ledsager denne voice-over, vises det, hvorledes den sidste uges klip er bundet sammen i kausale sammenhænge og kulminerer i en effekt, som rækker ud over det fiktive univers til fansenes respons på serien, som her bliver gjort til en del af fortællingen i kraft af kameraets urolige panorering over fangruppernes diskussioner i online fora. Det illustreres på den måde, hvordan det fællesskab og den effekt, der er sat i bevægelse af en initalt set ubetydelig norsk sommerfugl på en public service kanals ungdomssendeflade, tager form af et globalt fanfællesskab, der strækker sig fra Brasilien til Kina. Men det peger også på den betydning, feedbacket fra fansene har haft for serien, og i hvilken grad fansenes respons er en integreret del af serien på en måde som gør, at vi, hvis vi vil prøve at forstå seriens effekt, ikke kan tale om værk og faninteraktion som adskilte 
st $\varnothing$ rrelser. Vi må i stedet betragte helheden, som en sammenvævet masse, som seriens skabere har formået at operationalisere i fortællingens tjeneste. ${ }^{1}$

Det er denne amorfe masse, jeg i denne artikel forsøger at indkredse som forskningsobjekt ved at betragte det dynamiske digitale arkivs karakteristika som en afgørende forminspirator for serien. Digitale arkiver skal her forstås som den akkumulation af data, der i øjeblikket sker overalt i vores samfund under betegnelsen big data. Arkiver som ofte er karakteriseret ved at være uafgrænsede, dynamiske og i konstant bevægelse. De er ikke blot samlinger af fortidens artefakter eller dokumenter, som i en traditionel arkivopfattelse, men er samlinger af data, der peger ind i fremtiden og skaber nye spatio-temporale konfigurationer, idet de bruges til at forudsige alt fra forbrugsmønstre til sikkerhedsrisici. Sådanne former for dynamiske arkiver gennemsyrer vores samfund, og når den afsluttende tale til Sana, gengivet ovenfor, påpeger, at "[o]m 100 år har vi kanskje maskiner der kan utregne den nøyaktige effekt af hver eneste handling", så er det ganske givet den slags predictive analytics og machine learning-algoritmers arbejde med at kortlægge det, som voice-overen betegner som "kaosset" i vores eksisterende livsverden, der sigtes til. Samtidig er det også en fundamental narrativ funktion at "skabe orden i kaosset", at konfigurere begivenheder, karakterer og objekter på en meningsfuld måde for at skabe sammenhæng - det den franske filosof Paul Ricouer kalder konkordant diskordans. Udbredelsen af dynamiske digitale arkiver og big data-analyser, der vægter korrelation højere end kausalitet, har afgørende indflydelse på, hvordan vi tænker årsagssammenhænge i dag - og i denne artikel argumenterer jeg for, at de også giver genklang i de fortælleformer, der resonerer hos et publikum i det 21.århundrede.

I det $\varnothing \varnothing$ lgende vil jeg med udgangspunkt i litteraturteoretikeren Peter Brooks klassiske begreb om narrativt begær indkredse hvorledes formmæssige greb som gentagelsen, mellemrummene og en minut-for-minut tidslighed $\mathrm{i}$ SKAM medvirker til at binde et sådan amorft univers sammen på en måde, der i sjælden set grad formår at engagere fansene. Tilgangen her - som i denne artikels korte format nødvendigvis blot anslås - er på mange måder meget old-school narratologisk og fokuseret på form, hvilket kan synes paradoksalt $\mathrm{i}$ forhold til et mediemæssigt nybrud som SKAM, men jeg vil her argumentere for, at der i denne klassiske værktøjskasse gemmer sig redskaber til at forstå og afkode seriens akutte nutidige appel, som både indlejret i en længere kulturhistorie og knyttet til samtidskulturelle strømninger, der er tæe knyttet til de digitale mediers konfiguration af årsagssammenhæng og forløb.

\section{Værk som dynamisk arkiv}

Lad os i første omgang se nærmere på, hvordan SKAM som fænomen (der inkluderer hele mængden af NRKproduceret materiale på de forskellige medie-platforme, samt fan-interaktionen) kan forstås i relation til en udvidet såvel værk- som arkiv-forståelse. ${ }^{2}$ Med afsæt i den franske filosof Jacques Derrida, har medieteoretikeren Abigail Derecho brugt begrebet "archontic" til at beskrive fanfiktion, som hun karakteriserer som noget, der ikke er en afledning eller en kopi af en original, men har samme tendens mod udvidelse og akkumulation som arkivet (Derecho, 2006 s. 64-65). Det er værker, som ikke er afgrænsede enheder, men som udgør en dynamisk masse, der hele tiden udvider sig:

In fan fiction, there is a constant state of flux, of shifting and chaotic relation, between new versions of stories and the originary texts: the fics written about a particular source text ensure that the text is never solidified, calcified or at rest, but is in continuous play, its characters, stories, and meanings all varying through the various fics written about it. (ibid. s. 77)

SKAMs karakter af et univers, der udspiller sig både på seriens egen weblog, på Instagram og Youtube, samt i fanfora og på skuespillernes private profiler på sociale medier, gør dette udvidede arkivbegreb relevant i forhold til at begribe den svært afgrænselige værkstørrelse, vi har med at gøre. Jeg bruger dog, i modsætning til Derecho, i det følgende betegnelsen "faninteraktion" frem for fanfiktion, idet jeg ønsker at inkludere den respons, som ikke er fiktion, men kan være alt fra online diskussioner af det seneste klip til perlepladefigurer af karaktererne hængt op i byrummet. 
Med SKAM har vi altså ikke at gøre med et værk på den ene side og faninteraktion på den anden side som to adskilte størrelser, og hvor det kun er værket, der er fælles, mens faninteraktionen er partikulær. Netop fordi så meget af det, der produceres af NRK, som en del af SKAM universet, finder sted på Instagram, Youtube og i realtime, og derfor også er partikulært, bliver det nødvendigt også at følge med på fanfora, hvis man vil fange alt, hvad der sker i universet. Et eksempel er den had-konto som Pepsimax Gjengen i fjerde sæson opretter om Vilde (@ellevillevilde2), som eksisterede i så kort tid, at de fleste fans kun havde mulighed for at se, hvilke billeder og videoer, der var lagt ud, hvis de efterfølgende fandt dem i fanfora, hvor andre havde nået at tage et screenshot af dem. På samme måde gav de nye kontoer, der i kølvandet blev oprettet for flere af seriens $\varnothing v r i g e$ karakterer, anledning til spekulationer om, hvorvidt de formidlede hints om handlingen fra manuskriptforfatterenes side, eller om det var fan-producerede konti. Grænsen mellem, hvad der er fan-produceret, og hvad der er NRKproduceret, bliver på den måde flydende, og man kan derfor argumentere for, at SKAM ikke kan adskilles fra sin faninteraktion, men udgør et univers som både er værk og fan-interaktion. Selv hvis man kun ser serien i det mere traditionelle serie-format, som også tilbydes, når ugens klip samles til et afsnit, der publiceres hver fredag, har de aktive fans potentielt allerede sat deres mærke på handlingen. I hvert fald har producenterne effektivt fået skabt følelsen hos publikum af en sådan mulighed for at sætte sit aftryk eksisterer, blandt andet ved at der i sæson fire er der indarbejdet konkrete eksempler på fanart i seriens scener. Det er en form for interaktion med publikum, som potentielt kan virke opmuntrende på fansene i forhold til at engagere sig yderligere, og endda foranledige hierarkier blandt fans i forhold til, hvem der er mest aktive, opdager nye opslag først osv., hvilket alt sammen bidrager til øget engagement.

\section{Gentagelse}

Gentagelsen er et centralt greb i opbygningen af de fleste plots, fordi den bidrager til genkendelse og en opfattelse af fortællingen som en helhed, samtidig med at den retter læserens fokus mod noget, der særligt $\emptyset$ nskes fremhævet. I den nu klassiske Reading for the Plot fra 1984 ser litteraturteoretikeren Peter Brooks på, hvad der fastholder læserens interesse og engagement $\mathrm{i}$ en fortælling - det han kalder et narrativt begær. Med afsæt i Sigmund Freud og Walter Benjamin kobler han det narrative begær til en "anticipation of retrospection" (s. 23) og et begær efter slutningen som meningstilskrivende. Det narrative begær er således koblet til et begær efter slutningen som stand-in for den $d \varnothing d$, vi ikke selv har mulighed for at opleve i vores eget liv, og som også er en længsel efter mening. Her er gentagelsen som udskydelse en væsentlig komponent:

We emerge from reading Beyond the Pleasure Principle with a dynamic model that structures ends (death, quiescence, nonnarratability) against beginnings (Eros, stimulation into tension, the desire of narrative) in a manner that necessitates the middle as detour, as struggle toward the end under the compulsion of imposed delay, as arabesque in the dilatory space of the text. The model proposes that we live in order to die, hence that the intentionality of plot lies in its orientation toward the end even while the end must be achieved only through detour. (Brooks, 1984 s. 107-108)

Gentagelsen med små variationer er således en udskydelse af slutningen, men en udsættelse som er nødvendig for at meningstilskrivelsen overhovedet kan finde sted, fordi der i denne multiplikation ligger en erkendelsesproces, som er med til netop at gøre slutningen meningsfuld.

I SKAM bruges gentagelsen aktivt gennem serien $\mathrm{i}$ en række spejlingsscener, der går igen både internt $\mathrm{i}$ sæsonerne og mellem de forskellige sæsoner, men også i intertekstuelle gentagelser af scener fra andre film, som for eksempel Baz Luhrmanns Romeo \& Juliet i sæson tre. Disse gentagelser kan tage form af enslydende ordvalg, en gentagelse af baggrundsmusik eller visuel komposition. Eksempelvis ser vi i hver deres sæson hovedpersonerne Eva, Isak og Sana på vej ind i skolegården, når skammen og angsten for, hvad de andre tænker, tynger deres skuldre. Men gentagelsen figurerer også centralt i brugernes tilegnelse af serien, som man kan se i diskussionerne af de enkelte klip på for eksempel facebookgruppen Kosegruppa DK samt seriens egen weblog. Her rapporterer seerne jævnligt, at de ser de enkelte klip 10-20 gange. En seer-praksis som synes indbygget $\mathrm{i}$ de helt korte klip i og med at det hele tiden er en mulighed at gå tilbage og gense gamle klip og finde nye nuancer, intertekstuelle referencer og spejlinger til andre scener, mens man venter på, at der sker noget nyt $i$ realtiden. Hertil kommer en tredje form for gentagelse i form af fansenes bearbejdning af materialet i YouTube- 
videoer, fanfiktion, fanart, genskabelse af scener med dukker, fortolkningsfællesskaber i online diskussionsfora, osv.

Serien som helhed kan således ses som et katalog af klip, der kan hives frem og ses igen og igen i små bidder, der fungerer som afrundede entiteter, men ikke desto mindre er indlejrede i den fortløbende fortælling, som udgøres af i første omgang sæsonen og i et videre perspektiv serien som helhed, eftersom centreringen omkring den samme vennegruppe gør, at vi i senere sæsoner får tilføjet nye facetter til de historier, vi allerede tror er afsluttet. På grund af den serielle logik slutter fortællingen om Noora og William således ikke med sæson tos happy end. Fortællingen fortsættes og griber ind i de efterfølgende sæsoner som underplots, for eksempel $i$ trekantsdramaet mellem Sana, Yousef og Noora i sæson fire. Serien arbejder således både med afsluttede enheder, der kan ses og genses, og hvor nye betydningslag tilskrives, når de ses med den øgede viden, der fås ved retrospektion, men også med en konstant påmindelse af publikum om, at slutningen som meningstilskrivende ende blot er en placeholder, fordi livet fortsætter og nye betydninger til det allerede fortalte kan og vil komme til. Det narrative begær placeres således snarere i den konstante udvidelse, end i forventningen om en slutning som endepunkt, hvorfra betydning kan tilskrives.

\section{Mellemrum}

Et af SKAM's centrale greb er realtidsformatet, som betyder, at scener der foregår kl. 09.58 lørdag morgen også uploades kl. 09.58 lørdag morgen. Den fortalte tid og fortælletiden, er således sammenfaldende på en måde, der mimer en følelse af handlingen foregår live, som vi kender det fra TV-mediet. Ligesom i TV-mediet er det ikke afgørende, i hvor høj grad live-sendingen er en illusion. Det afgørende er den følelse af realtid der genereres. I forhold til følelsen af "liveness" på nettet skriver medieforskeren Tara McPherson:

This liveness foregrounds volition and mobility, creating a liveness on demand. Thus, unlike television which parades its presence before us, the Web structures a sense of causality in relation to liveness, a liveness which we navigate and move through, often structuring a feeling that our own desire drives the movement. The Web is about presence but an unstable presence: it's in process, in motion. (McPherson, 2006 s. 202)

Denne illusion om en realtidsoplevelse, som giver en fornemmelse af agens og indflydelse, er medvirkende til at mellemrummene mellem opslagene får en central position i fortællingens fremdrift. ${ }^{3}$ Ser man SKAM i realtid, kommer mellemrummene mellem nye opslag (i form af klip, sms-udvekslinger, Instagram-billeder osv.) relativt set til at fylde mere end opslagene selv, og de får deres egen vægt og signifikans, fordi de bruges med stor dramaturgisk effekt i spændingsopbygningen. For eksempel venter vi sammen med Noora på, at William svarer på hendes beskeder, efter at han i klippet "DET VERSTE SOM KAN SKJE" fra 20. maj $2016 \mathrm{kl} .14 .15$ stormede ud af skolegården. Det gør vi helt frem til klippet "WILLIAMMÅSVARE" fra den 25. maj 2016 kl. 14.13. I den mellemliggende periode har vi læst Nooras mere og mere desperate beskeder, pigegruppens fors $\varnothing \mathrm{g}$ på at st $\varnothing t t e$ hende, samt fulgt en fanskare som fik hashtagget \#williammåsvare og websitet harwilliamsvart.no til at gå viralt (Graatrud, 2016). Det tydeliggør den fællesskabsfølelse, som skabes blandt fansene omkring det at vente, samtidig med at det kobler sig til en intim og meget kropslig følelse af at svinge mellem agens og overgivelse til en anden, som de fleste af os kender, hvis vi går og venter på en vigtig besked og konstant tjekker vores telefon.

I modsætning til en "anticipation of retrospection" har vi således her at gøre med en tidslighed, som beror på en følelse af "liveness", og som i høj grad kan forstås gennem det digitale arkivs dynamiske form. Realtidsoplevelsen bidrager til en følelse af, at vores fiktive persongalleri lever deres liv simultant med vores, og at vi blot ind $i$ mellem og drypvist får indsigt $i$, hvad der foregår i deres liv (ligesom det er tilfældet med bekendtskaber, som vi måske sjældent møder fysisk, men hvis liv vi er opdateret på, fordi vi følger dem på sociale medier). Mellemrummene får dermed også en særlig vægt.

Som receptionsæstetikken har argumenteret for, har alle tekster små mellemrum, som består af det, der ikke bliver ekspliciteret i teksten. Den tyske litteraturteoretiker Wolfgang Iser kaldte dem "Leerstellen" (Iser, 1978). Det er de tomme pladser, læseren selv må udfylde. I de seneste 40 års diskussion af interaktivitet, som er fulgt i kølvandet på digital litteratur og spilforskning, hvor den form for læseraktivitet bliver gjort meget konkret, har 
debatten centreret sig om, i hvor høj grad indlevelse kræver, at læseren/brugeren/spilleren har indflydelse på tekstens handling (Aarseth, 1997; Ramsay, 2011). I SKAM er spørgsmålet imidlertid ikke, i hvor høj grad vi har medindflydelse på plottets fremdrift. Selvom fanart inkorporeres, og seriens skabere gør sit publikum opmærksomme på, at de følger med i fan-diskussionerne og bliver inspireret af dem, så er fanbasen overordnet set henvist til at vente på historiens fremadskriden uden direkte indflydelse på, hvornår det næste klip eller den næste chat lægges ud, eller hvad den indeholder, på trods af at realtidsillusionen mimer en følelse af handlemulighed og at der eksisterer en teoretisk mulighed for, at ens fan-aktivitet er blevet registreret af manuskriptforfatterne. Mellemrummene i SKAM bliver på grund af realtidsoplevelsen tidsligt udstrakt på en måde, der bevirker, at de bliver ekstremt betydningsskabende i fortællingen. Det er afgørende, om der går 3 timer eller 14 dage, inden William svarer. Som seer kan ventetiden føles næsten fysisk anstrengende og bidrager til en indlevelse i Nooras magtesløshed i forhold til at få ham i tale. Samtidig skaber mellemrum som disse et mulighedsrum for spekulationer, faninteraktion og for at gense tidligere klip i ventetiden. Mellemrummets dramaturgiske effekt ser vi i forstørret udgave i de pauser på mellem 10 og 18 dage, som forekommer midt i hver sæson, og som typisk kommer efter en kulmination i handlingen og efterfølges af en kort teaser, der giver et hint om, hvad der kommer til at ske i resten af sæsonen.

Det er altså ikke kun en forventning om tilbageblikkets meningstilskrivning, der driver fortællingen fremad $\mathrm{i}$ SKAM, men i lige så høj grad en arkivalsk akkumulativ logik, der gør narrativet til en åbnende bevægelse mod fremtiden. Ligesom gentagelserne fungerer mellemrummene som udvidelser af fortællingen og peger på en anden, dynamisk temporalitet.

\section{Minut for minut}

I SKAM ser vi således anslag til en narrativ temporalitet, som jeg her argumenterer for, udspringer af seriens dynamiske arkivlogik, der gør sig gældende både i den narrative opbygning af fortællingen og i den amorfe masse af faninteraktion med serien, som det ikke er muligt at skille fra selve serien som sådan. Når vi beskæftiger os med SKAM og det narrative begær, den vækker, må vi altså betragte fænomenet som en dynamisk masse $\mathrm{i}$ konstant udvikling, hvilket fundamentalt udfordrer idéen om slutningen, som det der tilskriver mening, eftersom fortællingen nødvendigvis aldrig når et afgrænset hele, men netop i kraft af sin dynamiske realtidsform mimer det levede liv. I denne artikel argumenterer jeg for, at vi ser en meningstilskrivning knyttet til gentagelsen og til mellemrummet, hvilket peger på en dynamisk arkivalsk temporal konfiguration af den narrative meningstilskrivning $\mathrm{i}$ et udvidet liveness-felt, der udfordrer en traditionel fortællings skematik i form af et forløb med en begyndelse, midte og slutning.

En sådan temporalitet finder vi tematisk måske tydeligst artikuleret i sæson tre. Her møder vi den bipolare Even, der i løbet af sæsonen veksler fra at være plaget af hektisk, manisk tankemylder til at være apatisk depressiv og selvmordstruet, og som tidligt i sæsonen udtrykker et ønske om "at kunne være regissør i sit eget liv", med andre ord at have narrativ kontrol over meningstilskrivning. Over for ham står hovedpersonen Isak, som er fascineret af muligheden for parallelle universer og en uendelighed, hvor "alt som kan skje, kommer til at skje, eller ikke bare kommer til at skje, det skjer". Begge karakterer gennemgår en udvikling i løbet af sæsonen, mens Isak lærer at få de forskellige parallelle universer, han har levet i for at skjule sin homoseksualitet, til at forenes i et "nu", hjælpes Even gennem depressionen og den angst for den uoverskuelige fremtid, der plager den depressive, i kraft af Isaks insisteren på at tage tingene "minutt for minutt". Der er altså en insisteren på nu'et som betydningsbærende, på samme måde som seerne tvinges af realtidsformatet til at følge fortællingens fremdrift $i$ en serie af nu'er, mens de ved hjælp af mellemrummene forhindres $i$ at binge-watche (undtagen som gentagelse), som man kan med serier på Netflix og HBO, der præsenterer hele sæsoner på én gang.

Den form for afhængighed, som serien foranledigede for mange af de fans, som fulgte den i realtid, skal netop ses i forhold til denne form for liveness i tidsforståelsen, som forstærker fansenes følelse af agens, omend de reelt ikke kan påvirke selve plottets fremdrift. Således udtrykt af en fan fra fanforumet Kosegruppa DK:

Åh jeg holder det ikke ud! 1+2 sæson blev binge watched. Så startede 3. sæson og jeg nøjedes bare med at se de første par afsnit om fredagen. Så kom pausen... forvirringen, savnet og frustrationen. Nu er jeg helt føkked! 


\begin{abstract}
Tjekker hele tiden hjemmesiden, mit hjerte hopper når der kommer nyt og jeg sover dårligt om natten. Og bruger alt for meget tid her i kosegruppan. Min kæreste ser på mig med bekymring i blikket og jeg forstår ham så godt...

Men hvorfor er der så få minutter i den her sæson!? I 2. sæson var der flere afsnit på over 40 minutter?! Og næsten dobbelt så mange minutter som i 1 . sæson. jeg vil have mere! ${ }^{4}$
\end{abstract}

Som citatet tydeligg ør er afhængigheden her en anden end binge-watching af en hel sæson, som trods alt giver en form for ro, når sæsonafslutningen nås (lidt ligesom når der ikke er flere lakridser i posen, og man derfor godt kan lægge den fra sig). Den konstante stimuli i en akkumulativ fortælling, som man både føler sig som en del af, i kraft af den indlevelse serien genererer, men som man også er prisgivet, fordi man ikke kan speede den op eller træffe aktive valg som i et computerspil, genererer en form for afhængighed, som er beslægtet med den efterhånden veldokumenterede afhængighed af sociale mediers nyhedsfeeds (Alter, 2017; Schüll, 2012). Det er en afhængighed, som netop er knyttet til en temporalitet, der performer et $n u$, som der hele tiden kan udvides og interageres med, og hvor gentagelser og mellemrum pulserer og bidrager til nuets udvidelse.

\title{
Fortælleformer og narrativt begær
}

At der er interaktion mellem de teknologiske muligheder, vi har til at fortælle historier med, og den form fortællinger antager, er langt fra en ny historie. De teknikker vi har til rådighed til at producere, opbevare, distribuere og konsumere tekst, lyd og billeder påvirker æstetiske værkers udtryksformer, ligesom disse ofte kan være med til at fremme udviklingen af nye teknologier. Tænk blot på Gutenbergs trykkemaskine, film- eller radiomediet og på de æstetiske værker, vi finder i perioden omkring deres fremkomst. ${ }^{5}$ Det gælder naturligvis også de digitale medier, som den ekstensive forskningslitteratur på området viser. ${ }^{6}$ I denne artikel har jeg argumenteret for, at den fortælleform, en netdramaserie som SKAM etablerer, har sin klangbund i det digitale arkiv som en dynamisk enhed og den særlige rumlige og tidslige konfiguration, som den digitale teknologis muligheder for produktion, opbevaring, distribution og konsumering af tekst, lyd og billeder skaber.

Som samtidskulturelt fænomen, står netdramaserien naturligvis ikke alene. Den skriver sig ind i en sammenhæng med andre genrer, der benytter sig af de sociale medieplatformes karakteristika. For eksempel Twitterfiktion, der som fænomen har været udfordret i forhold til at fastholde læserens opmærksomhed, når det myldrer med input fra det omkringliggende og konstant opdaterede nyhedsfeed. Det har medvirket til at gøre det til en relativt smal litteratur, som kun i sjælden grad har nået en større læserskare (Veel, 2016). I modsætning hertil har computerspil og digitale universer, der muliggør interaktion, og som ofte bygger på film- og tvserie successer, formået at skabe stor indlevelse i fiktive universer og at mobilisere en ellers potentielt distraherende tværmedial mediekultur i fortællingens tjeneste. Her har operationaliseringen af fans gennem sociale medier og i fanfiktionsfora medvirket til at udvide værkbegrebet og re-konfigurere afsender-modtager forholdet i det, Henry Jenkins (2006) i sin karakteristik af web 2.0 har kaldt "participatory culture".

SKAM synes ligeledes at have formået at skabe et univers med en ekstrem fanappel og indlevelse i seriens univers. Karakteristisk er den "afhængighed" mange fans beskriver, som bevirker, at de konstant opdaterer seriens website og nærmest har mere fokus på, hvad der sker i de fiktive karakterers liv end på deres egen dagligdag, til trods for at fortællingen foregår på flere medieplatforme og derfor om noget er i konkurrence med andre nyhedsfeeds. Hermed synes Twitterfiktionens udfordring omkring fastholdelse af opmærksomhed at være overkommet og erstattet af en næsten tvangsmæssig drift. Det er på den ene side i tråd med vores generelle sociale medieforbrug som potentielt afhængighedsskabende, men det er også, som jeg i denne artikel ved hjælp af brugen af gentagelsen, mellemrummene og minut-for-minut temporaliteten har argumenteret for, en nykonfiguration af det litteraturteoretikeren Peter Brooks har kaldt "narrativt begær". SKAM har været udråbt som banebrydende og nyskabende netop i sin brug af sociale medier, men det måske vigtigste at forstå i forhold til seriens rekonfiguration af et spatio-temporalt fortælle-rum skal formentlig findes i den måde, hvorpå serien er i dialog med det dynamiske digitale arkivs karakteristika og formår at omforme disse til et narrativt begær, der giver genklang hos sit publikum i 2017. 


\section{Referencer}

Aarseth, E. (1997). Cybertext: Perspectives on ergodic literature, Baltimore and London: Johns Hopkins University Press.

Alter, A. (2017). Irresistible: The rise of addictive technology and the business of keeping us hooked. London: Penguin Press.

Benjamin, W. (2005). The author as producer. I H. Eiland, M. W. Jennings \& G. Smith (eds), Walter Benjamin: Selected writings 2 (pp.768-783). Cambridge, MA: The Belknap Press of Harvard University Press.

Brooks, P. (1992). Reading for the plot: Design and intention in narrative. Cambridge, MA: Harvard University Press.

Bolter, J. D. (2001). Writing space: Computers, hypertext, and the remediation of Print. Mahwah, NJ: Lawrence Erlbaum Associates.

Derrida, J. (1996). Archive fever: A Freudian impression. Chicago: Chicago University Press.

Derecho, A. (2006). Archontic literature - A defintion, a history, and several theories of fan fiction. I K. Hellekson \& K. Busse (eds), Fan fiction and fan communities in the age of the internet. McFarland: McFarland Press.

Ensslin, A. (2014). Literary gaming. Cambridge, Mass.: MIT Press.

Graatrud, G. (2016). "Skam"-frustration skapte viral hit. Dagbladet. 25.maj.

https://www.dagbladet.no/kultur/skam-frustrasjon-skapte-viral-hit/60385310

Hayles, N.K. (2008). Electronic literature: New horizons for the literary. Notre Dame: University of Notre Dame Press.

Iser, W. (1978). The act of reading: A theory of aesthetic response. Baltimore: Johns Hopkins University Press. Jenkins, H. (2006). Fans, bloggers, and gamers: exploring participatory culture. New York \& London: New York University Press.

Karlskov, T., Vithner, M. \& Lentz, M. (2017). Otte skarpe til SKAM-skaberne: Instruktør besvarer spørgsmål fra dansk kosegruppa. DR.dk, posted 18.januar, opdateret 19.januar. https://www.dr.dk/nyheder/kultur/otteskarpe-til-skam-skaberne-instruktoer-besvarer-spoergsmaal-fra-dansk-kosegruppa

Kittler, F. (1997). Literature, media, information systems: Essays. Amsterdam: John Johnston.

Landow, G. P. (1992). Hypertext: The convergence of contemporary critical theory and technology. Baltimore: Johns Hopkins University Press.

McLuhan, M. (1994). Understanding media: The extensions of man. Cambridge, MA: MIT Press.

Ong, W. J. (2002). Orality and literacy: The technologizing of the word. New York: Routledge.

McPherson, T. (2006). Reload: Liveness, mobility and the web. I W. Hui Kyong Chun \& T. Keenan (eds.), New media. Old media: A history and theory reader. London: Routledge.

Murray, J. (1998). Hamlet on the holodeck: The future of narrative in cyberspace. Cambridge, Mass.: MIT Press. Postman, N. (1985). Amusing ourselves to death: Public discourse in the age of show business London: Penguin. Ramsay, S. (2011). Reading machines: Toward an algorithmic criticism. Urbana: University of Illinois Press.

Ricoeur, P. (1984). Time and narrative. Trans. Kathleen McLaughlin og David Pellauer. Chicago: University of Chicago Press. 
Rettberg, J. W. (2008). Blogging. Cambridge: Polity Press.

Ryan, M-L. (2015). Narrative as virtual reality 2: Revisiting immersion and interactivity in literature and electronic media. Baltimore: Johns Hopkins University Press.

Scholes, R., James Phelan and Robert Kellogg (2006). The Nature of Narrative. Oxford: Oxford University Press. Schüll, N. D. (2012). Addiction by design: Machine gambling in Las Vegas. Princeton, NJ: Princeton University Press.

Strate, L. (2014). Notes on narrative as medium and a media ecology approach to the study of storytelling. Between 4(8), 1-30.

Veel, K. (2016). Sites of uncertainty: The disruption of the newsfeed flow by literary tweets. Journal of Romance Studies, 16,1, 91-109.

\footnotetext{
${ }^{1}$ Seriens skabere lægger offentligt meget vægt på at fremhæve, at de følger med i fanfora og er i direkte dialog med deres publikum - ikke blot i kraft af de fokusgruppe-interviews de lavede som research inden serien blev til, men også løbende, mens serien kørte. Mari Magnus, der var ansvarlig for karakterernes online tilstedeværelse, viste til en præsentation på Techfestivalen i København 5. september 2017 en række eksempler på, hvordan de har fulgt med i fansenes diskussion og aktivt indarbejdet deres respons i serien. Her et citat fra et interview med DR: "Vi er afhængige af kontakten med publikum, som vi bliver inspireret af, for eksempel i form af musik og replikker, siger Mari Magnus og nævner, at de også høster inspiration fra kommentarfelterne på NRK's Skam-side. - Reaktionen på de sociale medier, da Eva var til eksamen i sæson 2, var en klar spejling af, hvordan pigerne i serien også følte, siger hun." (Karlskov, Vithner og Lentz).

2 Jerome McGanns arbejde med The Rosetti Archive (1993-2008) er et tidligt konkret eksempel på en udvidelse fra værk til arkiv. Her samles, i digitaliseret form, den engelske digter og kunstner Dante Gabriel Rossettis (1828-1888) produktion i form af både tekst og billeder, men også omfattende sekundærmateriale fra hans samtid, såvel som inspirationskilder tilbage fra 1300-tallet.

${ }^{3}$ I min læsning forholder jeg mig primært til SKAM som oplevet i realtidsformatet. Man kan argumentere for, at seeroplevelsen for efterfølgende generationer, som ikke har adgang til denne dimension, eller dem som i første omgang har valgt at se den i et traditionelt serie-format, vil have en anden temporal oplevelse af serien, men selv i disse tilfælde arbejder fortællingen med en illusion om realtid (McPherson).

4 Jeg har gennem sæson 3 og 4 fulgt både seriens egen weblog og Facebookgruppen Kosegruppa DK og indsamlet citater, der beskriver samme form for afhængighed, som ovenstående citat vidner om.

${ }^{5}$ En lang liste af kulturteoretikere har engageret sig i relationen mellem medier og narrativ form fra Walter Benjamin (2005) til Marshall McLuhan (1994), Walter Ong (2002), Neil Postman (1985), Friedrich Kittler (1997), George P. Landow (1992) og J. David Bolter (2011). Listen eksploderer i slutningen af det tyvende århundrede, og det er i dag svært at forestille sig kulturteori som ikke i en eller anden form relaterer sig til forholdet mellem medier og æstetisk form. Se eksempelvis Scholes et al. (2006) og Strate (2014).

${ }^{6}$ For eksempel Ensslin (2014), Hayles (2008), Murray (1998), Rettberg (2008), Ryan (2015).
} 